pp. 332-352

\title{
Impact of Structural Capital and Company Size on the Growth of Firm Value through Financial Performance with Good Corporate Governance as a Moderating Variable: Property and Real Estate Business in Indonesia
}

Submitted 12/07/20, $1^{\text {st }}$ revision 14/08/20, $2^{\text {nd }}$ revision 24/09/2020, accepted 10/10/2020

\author{
I Gusti Ngurah Bagus Gunadi ${ }^{1,2}$, I Gusti Bagus Wiksuana ${ }^{3}$, \\ Ida Bagus Anom Purbawangsa ${ }^{4}$, Henny Rahyuda ${ }^{5}$
}

\begin{abstract}
:
Purpose: This study aims to examine the role of good corporate governance in moderating the effect of capital structure and firm size on financial performance and its impact on the value of property and real estate companies in Indonesia.

Approach/Methodology/Design: The study population is a company incorporated in Indonesia's property and real estate industry and was listed on the Indonesia Stock Exchange (IDX) in 2013-2018. Data collection is done by distributing questionnaires offline and online using Google forms that have been tested with validity and reliability testing. The data analysis technique used is the SEM-PLS Analysis technique.

Findings: The results showed that the mechanism of good corporate governance in the form of board affiliation, the size of the board of directors, and the presence of an audit committee moderated the decision of capital structure and firm size that influenced financial performance and firm value. This study also proves the direct and indirect effect of capital structure decisions on financial performance and firm value. Another finding is the indirect effect of company size on firm value through financial performance.

Practical Implications: Board affiliation can reduce asymmetric information so that management will make decisions and act on shareholders' interests.

Originality/Value: Mechanism through good corporate governance and the use of debt as control over the manager's performance will reduce the occurrence of agency problems.
\end{abstract}

Keywords: Good Corporate Governance, board affiliation, capital structure, company size, financial performance, firm value.

JEL classification: G15, G32.

Paper Type: Literature review study.

ISSN: 2241-4754, H index 10, Q3.

${ }^{l}$ Doctoral Program, Faculty of Economics and Business, Udayana University, Bali,

Indonesia, e-mail: gunadinew2020@gmail.com;

${ }^{2}$ Faculty of Economic and Business, Mahasaraswati Denpasar University, Bali, Indonesia, email: gunadi@unmas.ac.id;

${ }^{3}$ Lecture Department of Management, Faculty of Economics and Business, Udayana,

e-mail:wiksuana@unud.ac.id;

${ }^{4}$ Same as in 3, e-mail: gigabagus@unud.ac.id;

${ }^{5}$ Same as in 3, e-mail: hennyrahyuda@unud.ac.id; 


\section{Introduction}

Company executives must understand the factors that influence the company's value so that they can formulate policies and decisions that are appropriate to achieve the company goals. The company's success in achieving its goals is largely determined by the quality of the manager's financial decisions. Some literature has reviewed and proved the effect of financial performance on firm value, as in the studies of Taani and Banykhaled (2011), Kabajeh et al. (2012), Alghifari et al. (2013), Dita and Murtaqi (2014), Sucuahi and Cambarihan (2016), and Kusmayadi et al. (2018).

One strategic decision that determines financial performance is the financing decision, which is closely related to determining the optimal structure capital. Jensen and Meckling (1976) argue that optimal structure capital will reduce agency costs and increase company value by encouraging managers to act in shareholders' interests. Higher debt can also reduce agency costs through monitoring activities by creditors against managers, in which case debt can act as a monitoring tool for debtholders. Research conducted by Abor (2007), Cai and Zang (2011), Barakat (2014), Isaac (2014), Asiri and Hameed (2014), Dita and Murtaqi (2014), Bokhari and Khan (2013), Borhan et al. (2014), Yaseen and Al Armaneh, (2015), Farooq and Masood (2016), prove that structure capital influences financial performance and firm value. Agency theory by Jensen and Meckling (1976) suggests that company size will affect company performance because of its impact on ownership structures that produce conflicts of interest. Studies by several researchers, including Becker et al. (2010), John and Adebayo (2013), Abbas et al. (2013), Niresh and Velnampy (2014), Husna and Satria (2019, prove that company size has a significant effect on financial performance and company value.

Good corporate governance (GCG) has become an important issue and attracted the international financial community's attention since the financial scandal that resulted in the downfall of several companies in Europe and America. Weak governance and the occurrence of corporate fraud and the financial crisis have raised awareness of the importance and acceleration in GCG implementation. The problem of GCG can be traced from the development of agency theory by Jensen and Meckling (1976), which explains how the parties involved in the company, including managers, company owners, and creditors, behave because these parties basically have different interests. The effectiveness of implementing GCG can be seen from the structure of corporate governance. The structure governance consists of the structure ownership, the board of directors, the board of commissioners, and the company committee.

The size of the board of directors is a crucial attribute in the structure management. Studies by Romano and Guerrini (2014), Zabri et al. (2016), Alabede (2016), Ashraf (2017) find that the size of the board of directors influences the effectiveness of decision making that affects financial performance. The audit committee's presence has a positive impact on financial performance, and it is important to create corporate accountability that can increase trust in financial statements (Laing and Weir, 1999). 
The audit committee will monitor the reporting process and financial transactions as well as assess the financial statements. The audit committee's role is to ensure the integrity of the financial statements, which is an important aspect of Alqatamin's GCG principles (2018). Research conducted by Abdur Rouf (2011), Aldamen et al. (2012), Akpey and Azembila (2016), Gunawan et al. (2014) stated that the audit committee greatly influenced the accountability of financial performance.

In-depth identification on the measurement of GCG variables is the existence of a family relationship between shareholders, directors, and commissioners of the company called board affiliation due to the dominance of family ownership in the company's ownership structure. The development of concepts in this research was pursued by placing GCG variables with the consideration that the GCG mechanism is part of supervision to overcome agency problems where the implementation of good corporate governance needs to be constantly monitored and strengthened so that consistent implementation quality is maintained to improve company performance and maintain investor confidence.

\section{Theoretical Background and Hypotheses}

\subsection{Good Corporate Governance and Board Affiliation in Indonesia}

The implementation of GCG has become a major concern in emerging market economies, including Indonesia. The issue of GCG began to emerge after Indonesia experienced a prolonged period of crisis since 1998. Many parties said that the long process of improving Indonesia's economic crisis was due to the weak GCG applied to companies in Indonesia. Since then, both the government and investors have begun to pay significant attention to Indonesia's GCG practices. Based on the composite disclosure index number, board quality, and risk disclosure in 2018, Indonesia is ranked fourth in ASEAN countries.

In Indonesia, the Law on the Company came into force in 1995 and was amended by Law No. 40 of 2007, stating that companies must adhere to a two-tier board system in the organizational structure, where there are boards of directors, management boards, and boards of commissioners as supervisory boards. There are clear differences regarding the functions of the board of directors and the board of commissioners. The existence of family ownership allows the phenomenon of a kinship system to place positions between the board of directors and the board of commissioners, which is called board affiliation. This study uses the term board affiliation, which is defined as a kinship or family relationship between shareholders and parties who serve as directors and commissioners.

The management structure of the Indonesian companies applies a two-board system consisting of a board of commissioners and a board of directors who have authority and responsibility by their respective functions (General Guidelines for Good Corporate Governance in Indonesia, 2006). Based on a survey from PwC Global 
(2018), 85\% of public companies in Indonesia are owned and managed by families, and only $15 \%$ of family ownership is not involved in management. The implication is the existence of affiliation of parties who sit on the company's board, especially directors and commissioners. The phenomenon that occurs is the kinship system in the placement of the board of directors and the board of commissioners, where there is still a kinship in the two chairs, which can be referred to as board affiliation. Many companies were initially family-owned companies, but eventually developed and became a public company. This has resulted in many cases where the board of commissioners and the board of directors are filled with people who are related by kinship, which can cause management discretion so that the supervisory function of the board of commissioners becomes less effective against the board of directors.

Shyu (2011) states that the family company has a share structure ownership dominated by the founding family and has a role in the management and corporate decision making. In the family business, family members also take control and have top management (Cheng, 2014). Anderson and Reeb's (2003) results prove that the performance of companies with family ownership is better than the performance of non-family firms, as well as when family members act as CEOs, company performance has increased compared to CEOs who are not family members.

Fama and Jensen (1983) stated that family ownership could reduce agency problems because, generally, the principal family ownership also acts as an agent, thereby increasing its value. Although family control in management and supervision functions can reduce agency problems, in the context of governance, it can lead to a conflict of interest that will influence decision making for personal interests that will harm minority shareholders and creditors. Lam and Lee (2008) state that the separation of roles of directors and commissioners in a company is unable to improve the oversight function if there is a family relationship between them.

Ismail and Mahfodz (2009) state that family companies have a high sense of belonging that determines owners care about the company's survival, so they have the drive to effectively control the company's performance. Furthermore, Bartholomeusz and Tanewski (2006) argued that family businesses have different governance mechanisms and structures than non-family firms that will affect company performance. Family ownership can also reduce agency problems caused by interests between shareholders and management, especially funding decisions.

The research results of Setia-Atmaja et al. (2009) stated that in companies controlled by families, using debt is greater than non-family control firms as a substitute for the independence director. This is because, generally, in a family company, shareholders also act as agents so that it will increase the value of the company (Fama and Jensen, 1983). Research by Hamberg et al. (2013), Ciftci (2019) proves that family ownership increases financial performance and firm value. The results of a study by Muttakin et al. (2014) show that family ownership has a significant positive effect on company performance. 


\subsection{Agency Theory}

Modern companies apply the separation between ownership and control functions of wealth (Berle and Means, 1932). The owner becomes the principal when they contract the executive to manage the company. The executive is morally responsible for maximizing shareholder utility. In modern companies, agents and principals are motivated by opportunities for personal gain. Agency theory describes the relationship between the principal and agent, where the principal is the party who gives the mandate to the agent. The principal delegates responsibility for decision-making to the agent where both parties' rights and obligations are described in a mutually beneficial work agreement. The agency theory assumes that humans are rational actors and individuals who always try to maximize their utility (Jensen and Meckling, 1976). If the utility functions of selfish agents and principals are compatible, there is no problem; both the agent and principal will receive an increase in their individual utility. The cost of an agency occurs when the interests of the principal and agent are different. The opportunities that exist allow agents to maximize their utility rationally.

\subsection{Structural Capital Theories}

In 1963, Modigliani-Miller published an article following their theory in 1958. The changed assumption was a tax on corporate income. They concluded that debt would increase the value of the company because the cost of debt interest is a cost that reduces tax payments. Using more debt means using cheaper capital (the cost of debt capital is smaller than the cost of capital stock) to reduce the weighted average cost of capital (although the cost of capital stock increases).

The Trade-off Theory (Modigliani and Miller 1963) in structure capital explains that in reality, there are things that make a company unable to use debt as much as possible. Trade-off theory shows conceptually that there is an optimal capital structure where the optimal amount of debt is determined by the trade-off between the benefits and losses of debt use (Liapis et al., 2020).

The signaling theory developed by Ross (1977) is one of the pillar theories in understanding financial management. Modigliani and Miller (1963) assume that investors have the same information about the company's prospects as managers, but in reality, managers have more information than outside investors. This is referred to as asymmetric information and is very influential on optimal structure capital decisions.

Signaling theory says that debt is used as a costly signal to inform public investors about the company's prospects so that in this case, the company will increase its use of debt. In this scenario, a company that dares to increase its debt is believed to have the ability to repay its debt, because only prospective companies are brave enough to take risks to increase their debt burden. Investors will judge and appreciate companies 
with a high debt burden compared to companies with low debt. Of course, in this case, the company in question must be an established company.

\subsection{Relationship between Variables}

\subsubsection{Effect of Structure Capital on Financial Performance and Firm Value}

Agency theory by Jensen and Meckling (1976) states that the use of debt will reduce agency costs where debt can act as a monitoring agent in increasing supervision by creditors so that managers will try to maximize resources to improve cash flow or company performance. Increased financial leverage will reduce conflicts between shareholders and managers regarding investment choices (Myers, 1977). If the debt is ratio high, the company can create and run investment opportunities that are profitable for investors to give a higher return than other companies. Theory of Modigliani and Miller (1963) suggested that the use of debt will increase the company's value because the cost of debt interest is the cost of reducing tax payments. Companies' use of debt will signal to outside investors about the creditor's confidence in the company's prospects. The higher the company's debt ratio shows, the greater the trust of external parties (creditors), so that it greatly influences investors' decision to invest their funds in the company. The results of Al-Taani's research (2013), Dita and Murtaqi (2014), Barakat (2014), Borhan et al. (2014), Setini et al. (2020), Farooq and Masood (2016), Data (2019), Hirdinis (2019) prove the effect of structure capital on financial performance and firm value.

H1: Structure capital has a positive and significant effect on the company's financial performance.

H2: Structure capital has a positive and significant effect on firm value.

H3: Financial performance has a significant role in mediating the effect of structure capital on firm value.

\subsubsection{Effect of Firm Size on Financial Performance and Firm Value}

The size of the company is an important factor in influencing a company's profitability, referring to the concept of economies of scale according to traditional neo-classical views. In large companies, production can be done at a lower cost than smaller companies. Also, large companies with abundant resources will be an opportunity for managers in addition to maximizing profits and maximizing their personal interests (Niresh and Velnampy, 2014; Putra et at., 2020). Large companies have greater growth so that the value of stock returns increases compared to small scale companies.

Becker et al. (2010), Abbas et al. (2013) prove that the company's size has a significant effect on company performance. Large companies with better market access have wider operational activities so that they have the possibility to get greater profits. The value of company assets becomes important information for investors informing investment portfolios. Management's ability to manage assets can be an assessment of investors against investment decisions in the capital market. Husna and Satria's 
research (2019) states that company size has a significant positive effect on firm value as measured by the price to book value ratio. Al-Slehat (2020) conducted a study on the effect of company size on firm value by using the Tobin'Q ratio proxy found that firm size had a significant positive effect on Tobin's $Q$ ratio.

H4: Firm size has a positive and significant effect on the company's financial performance.

H5: Firm size has a positive and significant effect on firm value.

H6: Financial performance has a significant role in mediating the effect of firm size on firm value.

\subsubsection{Effect of Financial Performance on Firm Value}

Jensen and Meckling (1976) explain several mechanisms that can be done to minimize agency problems for a company to reduce agency costs, and to be able to improve financial performance and firm value. Ross (1977) emphasizes how the optimal use of debt will improve the company's financial performance to become a positive signal for outside investors. Improved financial performance is a positive signal for investors to invest their funds in the company and affect stock prices. From the investor's point of view, to predict the company's prospects in the future, financial performance becomes a fundamental assessment before deciding to invest.

Research conducted by Sucuahi and Cambarihan (2016), Kabajeh et al. (2012) state that financial performance, as measured by the ratio of ROA, ROE, and NPM, has a significant positive effect on firm value. Luthfiah and Suherman (2018) found that the ratio of return on assets had a significant positive effect on Tobin's ratio Q. Alghifari et al. (2013) examined the effect of ROA and ROE on firm value as measured by price to book value and Tobin's Q ratio found the result that ROA and ROE significantly positive effect on firm value.

H7: Financial performance has a positive and significant effect on firm value.

\subsubsection{Moderation of Good Corporate Governance on the Effect of Capital Stucture and Firm Size on Financial Performance}

The owner's family still controls most companies, and the majority shareholders strongly influence managerial positions according to indications submitted by Laporta (1999) that the structure ownership in developing countries is still concentrated. Indonesia has a two-tier board system that requires a board of directors as managers and a board of commissioners as supervisors of the board of directors. Many companies were initially family-owned companies, but eventually developed and became a public company. The existence of kinship between directors and commissioners can lead to management discretion so that the board of commissioners' monitoring function becomes ineffective. In concentrated structure ownership, where the founding family still owns the majority of the ownership, board affiliation can actually unite shareholders' interests with the management. The existence of board affiliation in the company will influence financial decisions, especially funding and 
investment, and asset management as a company resource in generating profits. The greater the company's assets and the complexity level, the more effective management is needed. Shyu (2011) states that the family company has a share structure ownership dominated by the founding family and has a role in the management and corporate decision making. In the family business, family members also take control and have top management positions (Cheng, 2014). The results of Anderson and Reeb (2003) prove that the performance of companies with family ownership is better than the performance of non-family firms, as well as when family members act as CEOs, company performance has increased compared to CEOs who are not family members. Fama and Jensen (1983) stated that family ownership could reduce agency problems because, generally, the principal family ownership also acts as an agent, thereby increasing its value.

Jensen (1993) believes that a board of directors numbering eight or less will benefit the board's performance in the form of increased focus, participation, interaction, and useful debate. The need for several boards depends on the type of industry and its size. Research by Alabede (2016) and Ashraf (2017) proves that board size has a significant positive effect on financial performance. The audit committee is one of the committees required in the corporate governance mechanism (Cadbury, 1992). The audit committee's presence has a positive impact on financial performance, and it is important to create corporate accountability that will increase trust in financial statements (Laing and Weir, 1999). The study results from Gunawan et al. (2014) stated that the audit committee, as a GCG mechanism, had a significant positive effect on financial performance.

H8: Good corporate governance moderates the effect of structure capital on the company's financial performance.

H9: Good corporate governance moderates the effect of firm size on corporate financial performance.

Based on a theoretical study and the results of previous studies and the modified model, the conceptual framework of the research is displayed in Figure 1.

Figure 1. Research concept framework

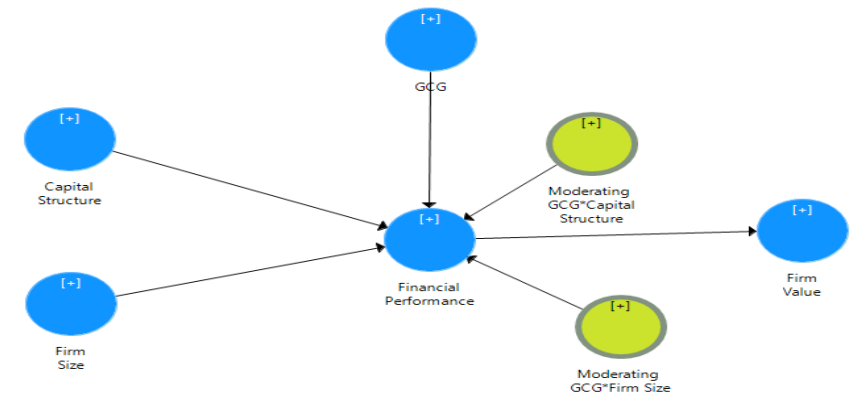

Source: Own study 


\section{Methodology}

Investment in the property and real estate sector is a long-term investment, so careful planning is needed to fulfill investment funds. Companies must consider the cost of capital with the benefits obtained during the current investment. When the debt ratio increases, the investor will require a higher level of profit. The structure of corporate governance that impacts the financial decision-making process in the property and real estate sectors needs to be strengthened to improve the effectiveness of governance and improve company performance and investor confidence. The study population is a company incorporated in Indonesia's property and real estate industry and was listed on the Indonesia Stock Exchange (IDX) in 2013-2018. Research data were obtained from firms' annual reports, external audit reports, corporate web pages of firms, and public disclosure platform. Details of the research variables and indicators on each variable are presented in Table 1.

Table 1. Classification of Research Variables

\begin{tabular}{|c|c|c|c|c|c|}
\hline \multirow{2}{*}{$\begin{array}{l}\mathbf{N} \\
\mathbf{0}\end{array}$} & \multirow{2}{*}{\multicolumn{2}{|c|}{ Variables }} & \multicolumn{2}{|l|}{ Measurement } & \multirow[b]{2}{*}{ Source } \\
\hline & & & Indicator & $\begin{array}{l}\text { Labe } \\
\text { l }\end{array}$ & \\
\hline \multirow[t]{2}{*}{1} & \multirow{2}{*}{$\begin{array}{l}\text { Structure } \\
\text { Capital/Exogenous }\end{array}$} & \multirow[t]{2}{*}{$\mathrm{X}_{1}$} & Debt to Equity Ratio & DER & \multirow{2}{*}{$\begin{array}{l}\text { Cai and Zang (2011); Ashraf et al. } \\
\text { (2017) }\end{array}$} \\
\hline & & & Debt to assets Ratio & DAR & \\
\hline \multirow[t]{2}{*}{2} & \multirow[t]{2}{*}{ Firm Size/Exogenous } & \multirow[t]{2}{*}{$\mathrm{X}_{2}$} & Natural Log Total Aktiva & LTA & \multirow{2}{*}{$\begin{array}{l}\text { Happ dan Schiereck, (2017); Asiri } \\
\text { and Hameed (2014) }\end{array}$} \\
\hline & & & Natural LogTotal Sales & LTS & \\
\hline \multirow[t]{3}{*}{3} & \multirow[t]{3}{*}{$\begin{array}{l}\text { Good Corporate } \\
\text { Governance/Moderat } \\
\text { ion }\end{array}$} & \multirow[t]{3}{*}{$\mathrm{M}_{1}$} & $\begin{array}{l}\text { Board Affiliation : kinship on } \\
\text { the company board and } \\
\text { shareholders }\end{array}$ & $\mathrm{BAF}$ & \multirow{3}{*}{ 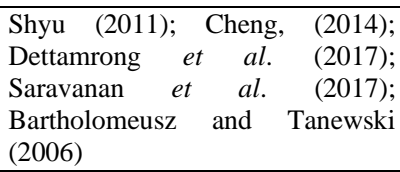 } \\
\hline & & & Board Size & BS & \\
\hline & & & Audit Committee & KA & \\
\hline \multirow[t]{2}{*}{4} & \multirow{2}{*}{$\begin{array}{l}\text { Financial } \\
\text { Performance/Mediati } \\
\text { on }\end{array}$} & \multirow[t]{2}{*}{$\mathrm{Y}_{1}$} & Return on assets & $R O A$ & \multirow{2}{*}{$\begin{array}{l}\text { Chen and Chen (2011); Sucuahi } \\
\text { and Cambarihan (2016); Niresh } \\
\text { and Velnampy, (2014) }\end{array}$} \\
\hline & & & Return on Equity & ROE & \\
\hline \multirow[t]{3}{*}{5} & \multirow{3}{*}{$\begin{array}{l}\text { Firm } \\
\text { Value/Endogenous }\end{array}$} & \multirow[t]{3}{*}{$\mathrm{Y}_{2}$} & Tobin's Q & TQ & \multirow{3}{*}{$\begin{array}{l}\text { Alghifari et al. (2013); Vo and } \\
\text { Minh (2014); Basyith (2016) }\end{array}$} \\
\hline & & & Price Book Value & $P B V$ & \\
\hline & & & Stock Return & SR & \\
\hline
\end{tabular}

Source: Own study.

The data analysis method in this study uses PLS (Partial Least Square) with Smart PLS 3.0 program tools. Analysis of the approach used is quantitative. The formal model in PLS defines latent variables as the aggregate linear of the indicators. Weight estimates for creating a component score of latent variables are obtained based on how the inner model (the structural model that links latent variables) and the outer model (the measurement model, is the relationship between indicators and constructs) is specified. The result is that the dependent variable's residual variance can be minimized (Hair et al. 2016).

\section{Results}

Descriptive statistics provide an overview of the average value (mean) obtained from variable data on corporate value, financial performance, structure capital, company 
size, and good corporate governance. The following are descriptive statistics of the research data shown in Table 2 below.

Table 2. Descriptive Statistics of Research Variables

\begin{tabular}{|l|l|l|l|l|}
\hline Construct & Min & Max & Mean & SD \\
\hline DER & 0.02 & 3.76 & 0.74 & 0.57 \\
\hline DAR & 0.02 & 0.79 & 0.37 & 0.17 \\
\hline LTA & 11.23 & 17.85 & 15.09 & 1.49 \\
\hline LTS & 8.67 & 16.27 & 13.24 & 1.72 \\
\hline OWN & 0.00 & 36.50 & 1.51 & 6.21 \\
\hline INT & 9.33 & 96.62 & 62.29 & 22.23 \\
\hline BS & 2.00 & 12.00 & 4.93 & 1.79 \\
\hline KI & 20.00 & 80.00 & 38.60 & 11.36 \\
\hline KA & 2.00 & 4.00 & 3.02 & 0.18 \\
\hline BAF & 0.00 & 1.00 & 0.63 & 0.48 \\
\hline GD & 0.00 & 50.00 & 17.73 & 16.85 \\
\hline ROA & -8.80 & 35.89 & 4.92 & 6.53 \\
\hline ROE & -22.25 & 18370.00 & 82.90 & 1170.75 \\
\hline NPM & -119.44 & 221.80 & 22.31 & 40.46 \\
\hline TOBINQ & 0.12 & 15.79 & 1.20 & 1.22 \\
\hline PBV & 0.10 & 12.77 & 1.51 & 1.67 \\
\hline SR & -0.88 & 11.58 & 0.11 & 0.88 \\
\hline
\end{tabular}

Source: Own study.

The evaluation stage of the measurement model / outer model is carried out to determine the validity and reliability of each indicator of latent variables with several criteria, namely convergent validity, discriminant validity, the average variance of extracted (AVE), and composite reliability. The structural model evaluation stage / inner model is carried out to determine the accuracy of the research model with several approaches, namely R-Square (R2), Q-Square Predictive Relevance (Q2), and Godness of Fit (GoF).

Figure 2. Model Estimation

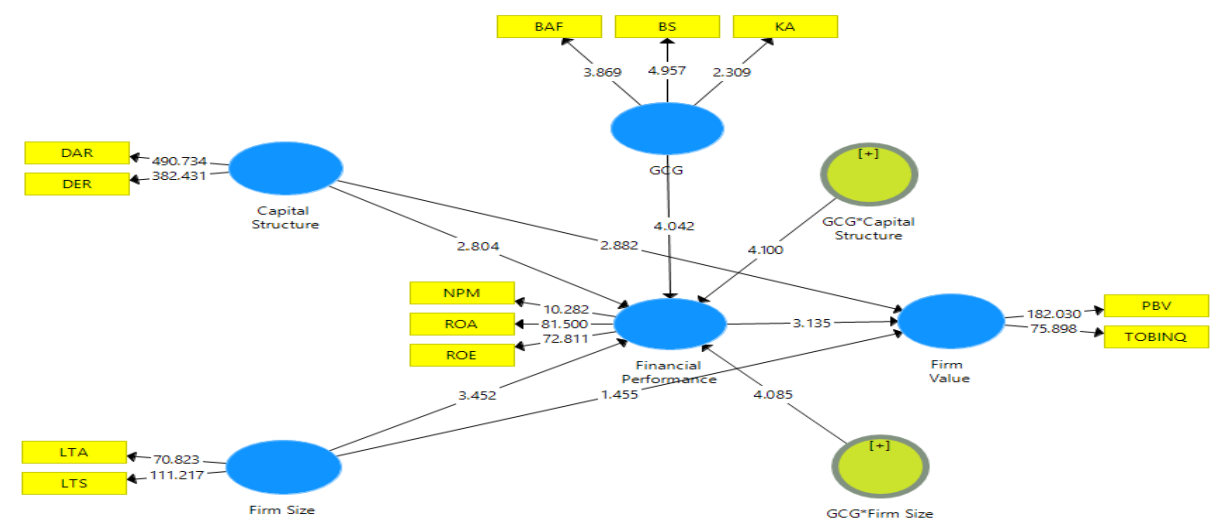

Source: Own study. 
Table 3. Construct Reliability and Validity

\begin{tabular}{|l|l|l|l|l|}
\hline & $\begin{array}{l}\text { Cronbach's } \\
\text { Alpha }\end{array}$ & rho_A & $\begin{array}{l}\text { Composite } \\
\text { Reliability }\end{array}$ & $\begin{array}{l}\text { Average Variance } \\
\text { Extracted (AVE) }\end{array}$ \\
\hline Capital Structure & 0.976 & 0.988 & 0.988 & 0.977 \\
\hline Financial Performance & 0.917 & 1.007 & 0.949 & 0.854 \\
\hline Firm Size & 0.955 & 1.154 & 0.977 & 0.954 \\
\hline Firm_Value & 0.949 & 1.013 & 0.974 & 0.950 \\
\hline GCG & 0.815 & 0.844 & 0.971 & 0.918 \\
\hline GCG* Structure Capital & 1.000 & 1.000 & 1.000 & 1.000 \\
\hline GCG*Firm Size & 1.000 & 1.000 & 1.000 & 1.000 \\
\hline
\end{tabular}

Source: Own study.

Table 4. Coefficient of Determination

\begin{tabular}{|l|l|l|}
\hline & R Square & R Square Adjusted \\
\hline Fnancial Performance & 0.611 & 0.568 \\
\hline Firm_Value & 0.649 & 0.621 \\
\hline
\end{tabular}

Source: Own study.

Testing the structural model or inner model in this study is determined based on several criteria, namely: R-Square, Q-Square Predictive Relevance, and Goodness of Fit. R-Square (R2) coefficient value of the financial performance variable is 0.611 . The coefficient value of the R-Square (R2) variable was obtained by the company value of 0.649 (Table 4).

\subsection{Hypothesis Testing Result}

The following table results from an analysis of each exogenous variable's direct and indirect effect on endogenous variables.

Table 5. Path Coefficients

\begin{tabular}{|l|c|c|c|c|c|}
\hline & $\begin{array}{c}\text { Original } \\
\text { Sample (O) }\end{array}$ & $\begin{array}{c}\text { Sample } \\
\text { Mean (M) }\end{array}$ & $\begin{array}{c}\text { Stand Dev } \\
(\text { STDEV) }\end{array}$ & $\begin{array}{c}\text { T Statistics } \\
(\mid \text { O/STDEV })\end{array}$ & P Values \\
\hline $\begin{array}{l}\text { Structure Capital_-> } \\
\text { Financial Performance }\end{array}$ & 0.215 & 0.214 & 0.114 & 2.804 & 0.007 \\
\hline $\begin{array}{l}\text { Structure Capital_-> } \\
\text { Firm_Value }\end{array}$ & 0.290 & 0.296 & 0.101 & 2.882 & 0.004 \\
\hline $\begin{array}{l}\text { Financial Performance -> } \\
\text { Firm_Value }\end{array}$ & 0.320 & 0.328 & 0.102 & 3.135 & 0.002 \\
\hline $\begin{array}{l}\text { Firm Size -> Financial } \\
\text { Performance }\end{array}$ & 0.421 & 0.410 & 0.122 & 3.452 & 0.001 \\
\hline $\begin{array}{l}\text { Firm Size -> Firm_Value Financial } \\
\text { GCG -> } \\
\text { Performance }\end{array}$ & 0.178 & 0.179 & 0.122 & 1.455 & 0.146 \\
\hline $\begin{array}{l}\text { GCG* Structure Capital_-> } \\
\text { Financial Performance }\end{array}$ & 0.279 & 0.280 & 0.093 & 4.042 & 0.000 \\
\hline $\begin{array}{l}\text { GCG*Firm Size -> Financial } \\
\text { Performance }\end{array}$ & 0.264 & 2.266 & 0.133 & 4.085 & 0.000 \\
\hline
\end{tabular}

Source: Own study. 
Table 6. Specific Indirect Effects

\begin{tabular}{|l|c|c|c|c|c|}
\hline & $\begin{array}{c}\text { Original } \\
\text { Sample (O) }\end{array}$ & $\begin{array}{c}\text { Sample } \\
\text { Mean } \\
(\mathrm{M})\end{array}$ & $\begin{array}{c}\text { Standard } \\
\text { Deviation } \\
(\text { STDEV) }\end{array}$ & $\begin{array}{c}\text { T Statistics } \\
(\mid \mathrm{O} / \mathrm{STDEV}) \\
)\end{array}$ & P Values \\
\hline $\begin{array}{l}\text { Structure Capital_ >> } \\
\text { Financial Performance -> } \\
\text { Firm_Value }\end{array}$ & 0.041 & 0.037 & 0.035 & 2.344 & 0.019 \\
\hline $\begin{array}{l}\text { Firm Size-> Financial } \\
\text { Performance } \\
\text { Firm_Value }\end{array}$ & 0.081 & 0.080 & 0.030 & 2.691 & 0.007 \\
\hline $\begin{array}{l}\text { GCG -> Financial } \\
\text { Performance } \\
\text { Firm_Value }\end{array}$ & 0.089 & 0.093 & 0.032 & 2.760 & 0.006 \\
\hline $\begin{array}{l}\text { GCG* Structure Capital_-> } \\
\text { Financial Performance -> } \\
\text { Firm_Value }\end{array}$ & 0.269 & 0.307 & 0.021 & 4.031 & 0.000 \\
\hline $\begin{array}{l}\text { GCG* Firm Size -> } \\
\text { Financial Performance -> } \\
\text { Firm_Value }\end{array}$ & 0.208 & 0.230 & 0.029 & 4.160 & 0.000 \\
\hline
\end{tabular}

Source: Own study.

The research hypotheses referred to Table 5 and Table 6 are as follows:

H1: Based on the analysis results in the Table, the t-statistic value of 2.804 with a pvalue of $0.007(\leq \alpha=5 \%)$ shows that the structure capital has a significant positive effect on financial performance so that the first hypothesis (H1) in this study is proven and acceptable.

H2: Based on the analysis results in the Table, the t-statistic value of 2.882 with a pvalue of $0.004(\leq \alpha=5 \%)$ shows that the structure capital has a significant positive effect on firm value so that the second hypothesis $(\mathrm{H} 2)$ in this study is proven and can be accepted.

H3: Based on the analysis results in the Table, the t-statistic value of 2,344 with a pvalue of $0,019(\alpha=5 \%)$ shows that financial performance has a significant role in mediating the effect of structure capital on firm value so that the third hypothesis (H3) in this study proven and acceptable.

H4: Based on the analysis results in the Table, the t-statistic value of 3,452 with pvalue of $0,001(\leq \alpha=5 \%)$ means that firm size has a significant positive effect on financial performance so that the fourth hypothesis (H4) in this study is proven and acceptable.

H5: Based on the analysis results in the Table, the t-statistic value of 1.455 is obtained with a $p$-value of $0.146(>\alpha=5 \%)$. This means that the size of the company does not affect the firm's value so the fifth hypothesis (H5) in this study is not proven and rejected.

H6: Based on the analysis results in the Table, the t-statistic value of 2.691 with a pvalue of $0.007(\leq \alpha=5 \%)$ is obtained which means that financial performance has a significant role in mediating the effect of firm size on firm value so that the sixth hypothesis (H6) in this study proven and acceptable. 
H7: Based on the results of the analysis in the table obtained t-statistic value of 3,135 with a p-value of $0,002(\leq \alpha=5 \%)$ this means that financial performance has a significant positive effect on firm value so that the seventh hypothesis (H7) in this study is proven and can be accepted.

H8: Based on the analysis results in the Table, the t-statistic value of 4.031 is obtained with a p-value of $0,000(\leq \alpha=5 \%)$. This means that the GCG variable moderates positively the effect of capital structure on financial performance so that the eighth hypothesis (H8) in this study is proven and acceptable.

H9: Based on the analysis results in the Table, the t-statistic value of 4.160 with a pvalue of $0.000((\alpha=5 \%)$ means that the GCG variable moderates positively the effect of firm size on financial performance so that the ninth hypothesis (H9) in this study is proven and acceptable.

\section{Discussion and Conclusion}

The results showed that structured capital had a positive and significant effect on financial performance. These results are consistent with the prediction of the first hypothesis that structure capital has a significant positive effect on financial performance. This finding's meaning is that increasing debt in the company's structure capital reflected by the debt to equity ratio and debt to asset ratio will improve financial performance as reflected in the ROA, ROE, and NPM ratios in property and real estate companies on the IDX.

The tendency to increase the use of debt in financing the projects carried out has provided a beneficial multiplier for the company. The higher the debt ratio shows companies' ability to create and run profitable investment opportunities that provide higher returns than other companies. Maximum efficiency and debt management has resulted in increased profitability and returns to shareholders. The use of corporate debt considers the trade-off between benefits and costs to determine the optimal mix of debt and equity so that the cost of capital becomes minimal.

The results of this study support the agency theory of Jensen and Meckling (1976), where the use of debt will reduce agency costs due to supervision by creditors so that managers will try to maximize resources to increase company cash flow. Creditors as lenders will do their utmost to supervise to ensure that the returned funds have been maintained. The results support Myers' (1977) statement that increasing financial leverage will reduce conflicts between shareholders and managers regarding investment choices. The manager will prioritize fulfilling obligations to creditors to reduce investment decisions that are considered less profitable for shareholders. As the company's debt ratio increases, risks arising from debt financing decisions such as interest costs will certainly increase financial risk. The findings of this study are consistent with the studies of Abor (2007), Al-Taani (2013), Ebrati et al. (2013), Setini et al. (2020), Borhan et al. (2014), Vijayakumaran (2017), Hirdinis (2019). 
This study's results are consistent with Modigliani and Miller's (1963) funding decision theory, which states that funding from debt will increase the value of the company due to tax savings from debt interest payments. The use of debt in the structured capital will be positively responded by investors and positively impact stock prices so that it will increase the value of the company. The results of this study are in line with research by Barakat (2014), Dita and Murtaqi (2014), Farooq and Masood (2016), Data (2019).

Companies with large assets have wider market access and operational activities, making it possible to obtain greater profits. The increase in the company's assets and sales reflects growth and productivity and is an expectation desired by management and investors. This finding shows that companies can maximize their resources to improve financial performance. From the perspective of agency theory, large companies with abundant resources will be an opportunity for managers to maximize profits and maximize their personal interests so that it has the potential to harm shareholders. Agency problems arise when wasteful actions in asset management and unfavorable decisions will interfere with company operations. Supervision from parties related to the company can minimize this, reducing agency costs and increasing profitability and company value. The results of this study are consistent with the studies conducted by Becker (2010), John and Adebayo (2013), and Missy et al. (2016), Hirdinis (2019), Husna and Satria (2019), and Al-Slehat (2020).

The size of the company indirectly affects the value of the company through financial performance. Large companies have professional human resources, sophisticated technology, and excellence in terms of economies of scale in the production process to produce lower costs than smaller companies. Large companies are also more diversified, and easy to access the market and receive a higher credit rating for each debt issued. These advantages become the strength of large companies to achieve growth through increased profitability. Increased profitability reflects a better prospect in the future and is a positive signal for investors to increase share prices and company value. This finding is by Chabachib et al. (2020), Kurniawansyah and Kurnianto (2020).

\section{The Effect of Financial Performance on Corporate Value:}

The results of the study prove that financial performance has a significant positive effect on firm value. This finding shows that profitable companies will attract investors because there are profitable prospects in the future. The results of this study indicate that investors consider the fundamental aspects of the company in buying shares. One of the company's fundamental factors is financial performance, as seen from profitability, which reflects the profitability of the financial investment. This study supports the agency theory of Jensen and Meckling (1976), which states that when a company can reduce agency costs, it will be able to improve financial performance that impacts firm value. This study's findings are also by the signaling theory, which states that increasing earnings is a signal that the company has good and profitable prospects so that investors are interested in buying company shares. The 
positive response from investors will increase share prices to increase the value of the company further. This study is by a study conducted by Alghifari et al. (2013), Dita and Murtaqi (2014), Karascus and Boskurt (2018).

\section{Moderation of Good Corporate Governance on the Influence of Structure Capital and Company Sizes on Financial Performance:}

The analysis shows that good corporate governance (GCG) moderates the effect of structure capital on its financial performance. Board affiliation, the board size, and the establishment of an audit committee as a GCG mechanism largely determine the company's strategic decisions in determining funding sources that impact improving financial performance and indirectly affect the value of the company. A familycontrolled company has an internal control mechanism through the dominance of the family on the company board. Board affiliation in a company board can unite shareholders and management's interests to influence the decision to determine the source of funds used in the structural capital. Board affiliation will reduce the impact of managerial discretion and moral hazard because management has an affiliation with the owner of most of the company's equity. The manager's decision to integrate sources of funds can minimize agency costs and balance risk and returns to increase financial performance. This study's results are by studies conducted by Fama and Jensen (1983), which state that family control can reduce agency problems because, in family companies, the principal also acts as an agent.

Based on descriptive statistics, the average number of boards of directors of property and real estate companies in this study was 5 people. Jensen (1993) states that a board of directors numbering eight or less will benefit the board's performance in the form of increased focus, participation, interaction, and useful debate. This is proven in this study where the number of directors' effectiveness as a GCG monitoring mechanism strengthens and determines the company's structure capital, which is oriented to improve financial performance. The results of this study are by the studies of Romano and Guerrini (2014), Alabede (2016), and Ashraf (2017), which state that board size influences financial performance.

The formation of an audit committee in assisting the duties of directors has resulted in maximum governance to create accountability in monitoring transactions and reporting processes that impact improving financial performance and corporate value. Decisions about using debt in a structured capital require effective oversight of transactions to produce efficient transaction costs. The results of this study are by the research of Abdur Rouf (2011), Laing and Weir (1999), Gunawan et al. (2014).

The results showed that good corporate governance (GCG) moderates company size's effect on the company's financial performance. The larger the company, the greater the problem's complexity so that it requires an effective oversight mechanism. One of the characteristics of a family company is direct control over management and supervision by affiliated parties to reduce the occurrence of agency problems and information asymmetry that impact making strategic corporate decisions, especially 
related to determining funding sources in the company's structure capital. As a party directly involved in the company's operations, management knows much about the actual business prospects that are not all known by the owner. The existence of board affiliation as part of the GCG mechanism will reduce the information asymmetry. The results of this study support Fama and Jensen (1983) in the scope of operations hypothesis, which states that the higher complexity requires a larger corporate board structure to provide more input to managers and access to information and resources needed by the company. The greater the company's size shows the growth and becomes an opportunity for companies to increase profitability and indirectly increase the company's value (Akinyomi and Adebayo, 2013). The GCG mechanism through board affiliation, the board size, and the existence of an audit committee in the company will directly influence management in deciding investment diversification that accommodates the interests of shareholders on projects that have high rates of return that will improve financial performance and indirectly will impact the value of the company.

\section{Research Implication:}

Theoretically, the results of this study show empirical evidence that supports agency theory Jensen and Meckling (1976) where the use of debt in structure capital will reduce agency costs due to increased supervision by creditors to managers so that managers will be more careful in their diversification strategies to maintain trust creditors as well as maximizing company resources to improve company performance. In line with the theories of Modigliani and Miller (1963) and Ross's signaling theory (1977), the results of this study indicate that the use of debt will increase the value of the company because of the benefits of tax reduction and give a positive signal to outside investors of creditor trust in the company's prospects in the future. The higher the debt ratio shows, the greater the trust of creditors, which greatly influences investors' decision to invest their funds in the company.

This study develops a theoretical model using GCG as a moderating variable on the effect of structure capital and firm size on financial performance. In-depth identification of the GCG mechanism in this study includes a series of affiliated relationships between the corporate board structure, shareholders, and other stakeholders. The theory of agency Jensen and Meckling (1976) explains how the parties involved in the company try to maximize their respective utilities to cause conflicts that can affect the company's performance and value. For this reason, an effective monitoring mechanism is needed to overcome agency problems in the company. GCG is one of the mechanisms used to monitor contract issues and limits the opportunistic behavior of management. The results of this study support the agency theory of Jensen and Meckling (1976) that an appropriate monitoring mechanism will reduce agency problems.

\section{Limitation and Future Research:}

This research was conducted in the property and real estate sector so that the generalization of research results was limited. Therefore, to get results and have better 
generalization power, further research should be limited to one sector and also to use other sectors. The study of governance (GCG) in this study needs to be developed because it is only based on secondary data findings. Further research can deepen the implementation of corporate governance through primary data obtained from company respondents to describe how corporate governance is implemented.

\section{Suggestion for Future Research:}

It is recommended for researchers who will develop this research by broadening the scope of the industrial sector under study as well as examining more in the forms of implementing GCG mechanisms in companies controlled by families and non-family companies by looking at aspects of board diversity such as competence and demographics that can determine decisions strategic in finance. Future studies can consider the impact of external factors in influencing management behavior in structure capital decisions, including macroeconomic conditions, government policies, and economic crisis.

\section{References:}

Abbas, A., Zahid, B., Zahid, M., Muhammad Nadeem A. 2013. Determinants of Firm Financial Performance. Business and Economic Research, 3(2), 76-86.

Abdur, R.M. 2011. The Relationship between Corporate Governance and Value of Firm in Developing Countries: Evidence from Bangladesh. The International Journal of Applied Economics and Finance, 5(3), 237-244.

Abor, J. 2007. Corporate Governance and Financing Decisions of Ghanaian Listed Firms. Corporate Governance, 7(1), 83-92.

Akinyomi, J., Adebayo, O. 2013. Effect of Firm Size on Profitability: Evidence from Nigerian Manufacturing Sector. Prime Journal of Business Administration and Management (BAM), 3(9), 1171-1175.

Akpey, I.G., Azembila, A.B. 2016. The Effect of Audit Committees on the Performance of Firms Listed on The Ghana Stock Exchange. IOSR Journal of Bussiness and Management, 18(11), 55-62.

Alabede, J.Ol. 2016. Effect of Board Diversity on Corporate Governance Structure and Operating Performance: Evidence from UK Listed Firm. Asian Journal of Accounting and Governance 7, 67-80.

Aldamen, H., Keith, D., Simone, K., McNamara, R., Nagel, S. 2012. Audit Committee Characteristics and Firm Performance During the Global Financial Crisis. Accounting and Finance, 52, 971-1000.

Alghifari, E.S., Sigi, Y.S., Juhaeni. 2013. Effect of Return on Aktivas (ROA) Against Tobin's Q: Studies in Food and Beverage Company in Indonesia Stock Exchange Years 20072011. International Journal of Science and Research (IJSR), 2319-7064.

Alqatamin, R.M. 2018. Audit Committee Effectivemess and Company Performance: Evidence from Jordan. Accounting and Finance Research, 7(2), 48-60.

Al-Taani, K. 2013. The Relationship Between Capital Structure and Firm Performance: Evidence from Jordan. Journal of Finance and Accounting, 1(3), 41-45.

Anderson, R.C., Mansi, S.A.,Reeb, D.M. 2003. Founding Family Ownership and The Agency Cost of Debt. Journal of Financial Economis, 68, 263-285.

Asiri, B.K., Hameed, S.A. 2014. Financial Ratios and Corporate's Value in The Bahrain Bourse. Research Journal of Finance and Accounting, 5(7), 1-9. 
Ashraf, M., Tayyeba, I., Sidra, T. 2017. Corporate Governance and Corporate Financing Decisions Impact on Firm Performance a Cement Industry Perspective of Pakistan. International Journal of Sciences: Basic and Applied Research, 36(3), 20-35.

Al-Slehat, Zaher, A.F. 2020. Impact of Financial Leverage, Size and Asset Structure on Firm Value: Evidence from Industrial Sector. International Business Research, 13(1), 109120.

Barakat, A. 2014. The Impact of Financial Structure, Financial Leverage and Profitability on Industrial Companies Shares Value (Applied Study on A Sample of Saudi Industrial Companies). Research Journal of Finance and Accounting, 5(1), 55-66.

Bartholomeusz, S., Tanewski, S.G. 2006. The Relationship Between Family Firms and Corporate Governance. Journal of Small Business Management, 44(2), 245-267.

Bokhari, H., Wadood, K., Arif, M. 2013. The Impact of Capital Structure on Corporate's Performance a Case of Financial Sector of Pakistan. European Journal of Business and Management, 5(31), 111-137.

Borhan, H., Mohamed, N.R., Azmi, N. 2014. The Impact of Financial Ratios on the Financial Performance of a Chemical Company: The Case of Lyondell Basell Industries. World Journal of Entrepreneuship, Management and Sustainable Development (WJEMSD), $10(2)$.

Basyith, A. 2016. Corporate Governance, Intellectual Capital and Firm Performance. Research in Applied Economics, 8(1), 17-41.

Becker, B, Kaen, R.J., Ahmad Etebari, F.R., Hans, B. 2010. Employees, firm size and profitability in US manufacturing industries. Investment Management and Financial Innovations, 7(2), 7-23.

Cai, J., Zhang, Z. 2011. Leverage Change, Debt Overhang, and Stock Prices. Journal of Corporate Finance, 17, 391-402.

Chabachib, M., Hersugondo, H. ,Ardiana, E., Pamungkas, I.D. 2020. Analysis of Company Characteristics of Firm Values: Profitability as Intervening Variables. International Journal of Financial Research, 11(2), 60-70.

Cheng, Q. 2014. Family Firm Research - A Review. China Journal of Accounting Research, 7, 149-163.

Ciftci, I., Tatoglu, E., Wood, G., Demirbag, M., Zaim, S. 2019. Corporate Governance and Firm Performance in Emerging Market:Evidence from Turkey. International Business Review, 28, 90-103.

Data, A. 2019. The Effect of Aktiva Use Activities on Capital Structure, Business Risk, Financial Performance and Corporate Value (Study of Manufacturing Industry Companies in the Indonesia Stock Exchange). European Journal of Business and Management, 11(36).

Detthamrong, U., Nongnhit, C., Chaiporn, V. 2017. Corporate Governance, Capital Structure and Firm Performance: Evidence from Thailand. Research in International Bussiness and Finance, 42, 689-709.

Dita, A.H., Murtaqi, I. 2014. The Effect of Net Profit Margin, Price to Book Value and Debt to Equity Ratio to Stock Return in The Indonesian Consumer Goods Industry. Journal of Business and Management, 3(3), 305-315.

Ebrati, M.R., Emadi, F., Balasang, R.S., Safari, G. 2013. The Impact of Capital Structure on Firm Performance. Evidence From Tehran Stock Exchange. Australian Journal of Basic and Applied Sciences, 7(4), 1-8.

Fama, E.F. 1980. Agency Problem and Theory of The Firm. Journal of Political Economy, $38,288-307$. 
Fama, F.E., Jensen, C.M. 1983. Separation of Ownership and Control. Journal of Law and Economics, 36.

Farooq, M., Masood, A. 2016. Impact of Financial Leverage on Value of Firm: Evidence from Cement Sector of Pakistan. Research Journal of Finance and Accounting, 7(9), 73-77.

Gunawan, R.M.B., Effendie, D.B. 2014. The Influence of Good Corporate Governance, Ownership Structure and Bank Size to The Bank Performance and Company Value in Banking Industry in Indonesia. European Journal of Bussiness and Management, 6(24), 9-20.

Hair, J.E Jr., Thomas, G., Hult, M., Ringle, C., Sarstedt, M. 2016. A Primer on Partial Least Squares Structural Equation Modelling (PLS-SEM). SAGE Publication, California.

Hamberg, M., Fagerland, A., Kvamme, E., Nilsen, K. 2013. Founding Family Firms and The Creation of Value: Swedish Evidence. Managerial Finance, 39(10), 963-978.

Happ, C., Schiereck, D. 2017. Seasoned Equity Offerings and Corporate Governance in Europe. Journal of European Real Estate Research, 10(2), 170-194.

Hirdinis, M. 2019. Capital Structure and Firm Size on Firm Value Moderated by Profitability. International Journal of Economics and Business Administration, 7(1), 174-191.

Husna, A., Satria, I. 2019. Effect of Return on Aktiva, Debt to Aktiva Ratio, Current Ratio, Firm Size and Dividend Payout Ratio on Firm Value. International Journal of Economics and Financial Issues, 9(5), 50-54.

Isaac, L. 2014. Capital structure and corporate's market value in Nigeria. Research Journal of Finance and Accounting, 5(12), 16-31.

Ismail, N., Mahfodz, A.N. 2009. Succession Planning in Family Firms and its Implications on Business Performance. Journal of Asia Entrepreneurship and Sustainability, 10(3), 86-107.

Jensen, M., Meckling, W. 1976. Theory of The Firm: Managerial Behavior, Agency Costs and Ownership Structure. Journal of Financial Economic, 3, 305-360.

Jensen, M.C. 1986. Agency Cost of Free Cash Flow, Corporate Finance and Take Over. American Economic Review, 76, 323-329.

Jensen, M.C., Gerald, R., Donald, P., Solberg, T., Zorn, S. 1992. Simultaneous Determinations of Insider Ownership, Debt and Dividends. Journal of Financial and Quantitative Analysis, 27, 247-263.

Jensen, M.C. 1993. The Modern Industrial Revolution, Exit and The Failure of Internal Control System. Journal of Finance, 48, 831-880.

Kabajeh, M.A.M., Nu'aimat, S.M.A., Dahmash. 2012. The Relationship Between the ROA, ROE and ROI Ratios with Jordanian Insurance Public Companies Market Share Price. International Journal of Humanities and Social Science, 2(11), 115-120.

Karakus, R., Boskurt, I. 2017. The Effect of Financial Ratios and Macroeconomics Factor on Firm Value: An Empirical Analysis in Borsa Istanbul. RSEP International Conference on Social Issues and Economics Studies, ISBN 978-605-307-685-8.

Kurniawansyah, D., Kurnianto, S. 2020. The Influence of Corporate Social Responsibility, Corporate Governance and Firm Size on The Value of Manufacturing Companies in Indonesia: Profitability as Mediation. International Journal of Innovation, Creativity and Change, 10(12), 448-462.

Kusmayadi, D., Rahman, R., Abdullah, Y. 2018. Analysis of the Effect of Net Profit Margin, Price to Book Value and Debt to Equity Ratio on Stock Return. International Journal of Recent Scientific Research, 9(7), 28091-28095. 
Laing, D., Weir, M.C. 1999. Governances Structures, Size and Corporate Performance in UK Firms. Management Decision, 37(5), 457-464.

Lam, T., Yan, S., Kam, L. 2008. CEO Duality and Firm Performance: Evidence From Hong Kong. Corporate Governance: The International Journal of Bussiness in Society, 8(3), 299-316.

La Porta, R., Lopez de Silanes, F., Shleifer, A. 1999. Corporate Ownership Around The World. Journal of Finance, 54, 471-571.

Liapis, J.K., Politis, D.E., Ntertsou, D., Thalassinos, I.E. 2020. Investigating the Relationship between Tax Revenues and Tax Ratios: An Empirical Research for Selected OECD Countries. International Journal of Economics and Business Administration, 8(1), 215-229. DOI: $10.35808 / \mathrm{ijeba} / 420$.

Luthfiah, A., Suherman, A. 2018. The Effects Of Financial Performance Toward Firm Value With Ownership Structure As Moderating Variable (The Study On Manufacturing Companies Listed In Indonesia Stock Exchange In The Period Of 2012-2016. Journal of Business and Behavioral Entrepreneurship, 2(1), 18-27.

Missy, Y., Budiyanto, B., Riyadi, S. 2016. Influence of Capital Structure, Size and Growth on Profitability and Corporate Value. International Journal of Bussiness and Finance Management Research, 4, 80-101.

Modigliani, Franco, Miller, Merton H. 1958. "The Cost of Capital, Finance and The Theory of Investment”, American Economic Review, 48(48), 261-297.

Modigliani, F., Miller, M.H. 1961. Dividend policy, growth, and the valuation of shares. The Journal of Business, 34(4), 411-433.

Modigliani, F., Miller, M.H. 1963. Income Taxes and The Cost of Capital: A Correction. American Economic Review, 53(3), 433-443.

Muttakin, M.B., Khan, A., Subramaniam, N. 2014. Family Firms, Family Generation and Performance: Evidence from an Emerging Economy. Journal of Accounting in Emerging Economies, 4(2), 197-219.

Myers, S.C. 1977. Determinants of Corporate Borrowing. Journal of Financial Economics, 5(2), 147-175.

Myers, S.C. 1984. The Capital Structure Puzzle. Journal of Finance, 39, 572-592.

Myers, S.C., Majluf, N.S. 1984. Corporate Financing and Investment Decisions When Firms Have Information That Investors Do Not Have. Journal of Financial Economics, 187221.

Myers, S.C. 2001. Capital Structure. Journal of Economics Perspective, 15(2), 82-102.

Niresh, V. 2014. Firm Size and Profitability: A Study of Listed Manufacturing Firms in Sri Lanka. International Journal of Business and Management, 9(4), 57-64.

Orjinta, H.I., Iwueze, N.E. 2018. Effect of Audit Committee Characteristics on Performance of Non-Financial Firms: Evidence From a Recessed Economy. International Journal of Innovation and Applied Studies, 24, 289-298.

Putra, I., Sunarsih, N., Novitasari, L., \& Setini, M. 2020. Exploring the relationship between social capital, innovation capability and innovation during the coronavirus pandemic. Uncertain Supply Chain Management, 8(4), 857-864.

Romano, G., Guerrini, A. 2014. The Effects of Ownership, Board Size and Board Composition on The Performance of Italian Water Utilities. Utilities Policy, 31, 1828.

Ross, S.A. 1977. The Determination of Financial Structure: The Incentive Signaling Approach. Bell Journal of Economics, 8, 23-40. 
Saravanan, P., Srikanth, M., Avabruth, S.M. 2017. Compensation of Top Brass, Corporate Governance and Performance of The Indian Family Firms an Empirical Study. Social Responsibility Journal, 13(3), 529-551.

Setia-Atmaja, L., Tanewski, S.G., Skully, M. 2009. The Role of Dividends, Debt and Board Structure in the Governance of Family Controlled Firms. Journal of Business Finance \& Accounting, 36(7-8), 863-898.

Setini, M., Yasa, N.N.K., Gede Supartha, I.W., Ketut Giantari, I., Rajiani, I. 2020. The Passway of Women Entrepreneurship: Starting from Social Capital with Open Innovation, through to Knowledge Sharing and Innovative Performance. Journal of Open Innovation: Technology, Market, and Complexity, 6(2), 25.

Shyu, J. 2011. Family Ownership and Firm Performance: Evidence from Taiwanese Firms. International Journal of Managerial Finance, 7(4), 397-411.

Sucuahi, W., Cambarihan, J.M. 2016. Influence of Profitability to The Firm Value of Diversified Companies in the Philippines. Journal of Accounting and Finance Research, 5(2), 149-153.

Taani, K., Banykhaled, M.H.H. 2011. The Effect of Financial Ratios, Firm Size and Cash Flows from Operating Activities on Earnings Per Share (an Applied Study: on Jordanian Industrial Sector). International Journal of Social Sciences and Humanity Studies, 3(1), 197-205.

Vijayakumaran, R. 2017. Capital Structure Decisions and Corporate Performance: Evidence From Chinese Listed Industrial Firm. International Journal of Accounting and Financial Reporting, 7(2), 562-576.

Vo, Duc Hong, Nguyen, Tri Minh. 2014. The Impact of Corporate Governance on Firm Performance: Empirical Study in Vietnam. International Journal of Economics and Finance, 6(6), 1-13.

Yaseen, H., Al Amarneh, A. 2015. Corporate Governance and Financial Leverage: Evidence from Jordan. Research Journal of Finance and Accounting, 6(12), 180-187.

Zabri, S.M., Kamilah, A., Khaw, K.W. 2016. Corporate Governance Practices and Firm Performance: Evidence from Top 100 Public Listed Companies in Malaysia. Procedia Economics and Finance, 35, 87-296. 